6. Нормативність актів судової влади в англо-саксонській правовій системі: управлінський аспект / I. С. Туркіна // Публічне управління: теорія та практика. - 2013. - Вип. 1. - С. 21.

DOI https://doi.org/10.30525/978-9934-26-040-7-14

\title{
КАТЕГОРИИ «НЕЗАПАМЯТНОЙ ДАВНОСТИ», «ИСКОВОЙ ДАВНОСТИ» И ЗО-ЛЕТНИЙ СРОК КАК ОСНОВА ДЛЯ НЕЗАВИСИМОСТИ И САМОСТОЯТЕЛЬНОСТИ В УПРАВЛЕНИИ УПЦ
}

\author{
Ухтомский А. А. \\ протоиерей, кандидат богословия, \\ преподаватель Истории Европы и Истории Древних Восточных \\ Церквей Киевской Духовной Академии и Семинарии \\ г. Киев, Украина
}

Категории «незапамятной давности» и «исковой давности» регламентируют время наступления и прекращения осуществления права пользования той или иной вещью, имуществом.

Незапамятная давность, характеризует время действия права в течение такого продолжительного срока, что уже никто не помнит, когда произошло его осуществление впервые, «если современники о нем только знают, а о другом не слышали даже и от своих предков» [1, с. 170]. В таком случае предполагается, что это право однажды было приобретено на основании особого законного постановления или на каком-либо правомерном основании [10]. Русский юрист, доктор римского права XIX - XX вв. Давид Давидович Гримм замечает: «Факт осуществления данного права с незапамятных времен освобождает от обязанности доказать, каким образом было приобретено право. Это так называемая незапамятная давность, praescriptio immemorialis или indefinita. Незапамятная давность признавалась римским правом под названием vetustas в известных случаях, она получила дальнейшее развитие в каноническом праве и была распространена практикою на все роды прав» [2, с. 47]

Наряду с незапамятной давностью существует понятие «исковая давность», погашение иска в случае отсутствия, непредъявления его в 
течение срока давности. Т. е. в случае непредъявления и неосуществления защиты заинтересованным лицом в течение определенного времени, наступает погашение возможности процессуальной защиты. Понятие «исковой давности» введено в 424 г. с установленным сроком в 30 лет. Т. е. действие исковой давности наступает через 30 лет. «Новый закон основан на том соображении, что то, что́ не было осуществлено в течение целого человеческого века, не должно уже нарушать спокойствия настоящего. По искам церкви и богоугодных заведений и для actio hypothecaria установлены 40-летние сроки (для Католической Церкви - прим. А. У.)» [10].

Подытожим вышеизложенные разъяснения о категориях незапамятной давности и исковой давности. Понятие незапамятной давности подразумевает владение, пользование чем-либо на основании установленного закона или правила с того времени когда уже этого никто не помнит, предположительно 30-летней давности. Оспорить это право можно в течение 30-летнего срока, после истечения этого которого, наступает положение исковой давности, когда иск подать не представляется возможным и целесообразным. Почему? На этот вопрос остроумно отвечает юрист Барон: «что́ не было осуществлено в течение целого человеческого века, не должно уже нарушать спокойствия настоящего» [1, с. 170].

Категории римского права «незапамятная давность» и «исковая давность» стали формальным основанием для подобных категорий канонического права. Сюда можно отнести, например, узаконение обычая управления епархии одним епископом сроком свыше 30 лет. «В гражданском праве обычай может существовать самостоятельно, основываясь на непосредственном общественном убеждении; в церковном праве он находится в зависимости от известного предания или, по крайней мере предпочитает последнее и служит одной из форм выражения преданной истины» [5, с. 49].

Критерии признания церковного обычая законом таковы:

1) Предмет обычая должен иметь строго церковный характер, содержать истину. Священномученик Киприан Карфагенский (III в.) в письме к Помпею пишет: «Незаметно утвердившийся обычай не должен служить препятствием к победе и утверждению истины. Ибо обычай без истины есть только старое утверждение» [3, с. 308]; Климент Александрийский (II-III в.) в Строматах» пишет: «Люди, склонные к поиску наиболее совершенного, никогда не признают чтолибо истинным, прежде чем найдут подтверждение тому в Писании» $[4$, c. 252$]$ 
2) Обычай не должен быть душевредный и пагубный. Об этом свидетельствует прп. Никодим Святогорец в толковании на 1-е правило Сердикского собора: «подобает ниспровергать всякий дурной и душевредный обычай и разрушать его до самых оснований, а всякий добрый и полезный обычай упрочивать и сохранять» [6, с. 201]. Далее автор приводит свидетельства святителя Иоанна Златоуста и святителя Василия Великого и др.

3) Цель обычая должна согласовываться с целью Церкви - спасение людей [5, с. 49-50].

4) Давность. В толковании на слова 17-го правила Двукратного Собора: «Редко бывающаго, не поставляя в закон Церкви, определяем...» преподобный Никодим Святогорец сообщает: «Частные и редкие случаи, вызванные обстоятельствами, не становятся всеобщим законом для Церкви» [6, с. 37]. Далее он приводит слова святителя Григория Богослова и выдержки из 2-го деяния Собора в святой Софии: «Хорошее, но редко случающееся не может быть законом для многих» [6, с. 37]. «В православном церковном праве таких четких указаний на давность обычая нет, но в 17-м правиле IV Вселенского Собора и в 25-м правиле Трулльского Собора устанавливается 30летняя давность существования границ между епархиями для признания их законности. По аналогии с этим правилом можно предположительно говорить о необходимости тридцатилетней давности для признания законной силы обычая» $[9$, с. 33].

5) Обычай не должен противоречить писаному закону. Никодим Святогорец ссылаясь на слова 6 новеллы императора Льва Мудрого где он пишет, что не должен иметь силу неписанный обычай, запрещаемый правилами, сообщает: «Хотя обычай имеет силу неписанного закона, а в гражданских делах давний обычай даже получает силу закона, однако не во всем подряд, но там, где нет писанного закона и где это не противоречит писанному закону или правилу» [7, с. 60]. Согласно 2 кн. «Василик» (тит. 1, гл. 41) и Арменопулу «Обычай имеет силу писанного закона, однако не вообще, неопределенно и всегда, но лишь тогда, когда этот обычай укреплен и утвержден на суде в тех делах, относительно которых писанного закона нет, и когда обычай не противоречит писанному закону, является благоразумным, законным, справедливым и насажден с добрым намерением, будучи испытан знаменитыми мужами, согласно Арменопулу (кн. 1, тит. 1). А все обычаи безрассудные и неподобающие соблюдать не следует, по словам того же Арменопула» [6, с. 201-202].

Итак, из церковных правил и их толкований видно, что законодательно утвержденный обычай вобрал в себя такие категории 
римского права как «незапамятная давность» и «исковая давность», наиболее ярко выраженные в 17 пр. IV Вселенского Собора и 25 пр. Трулльского собора. Именно рассмотрение обычая через призму этих двух категорий, помогает понять значимость обычая как социальной нормы поведения. Конечно, здесь мы имеем ввиду обычай содержащий истину, соответствующий цели Церкви, не душевредный и не пагубный, имеющий определенную давность, не противоречащий писанному закону. Что касается срока давности (срока «незапамятной давности» по римскому праву), этот срок установлен в 30 лет, означая этим срок, после которого невозможно подать иск против действующего на этой территории епископа, если он только не захватил власть силой. Иными словами, управление епископом территорией на основании сложившегося обычая становится правом и защищается только спустя тридцать лет беспрепятственного управления при отсутствии посягательства на данную территорию. Разрешить возникший спор может собор области, митрополит и, в конце концов, Вселенский патриарх. Последний, не имеет права разрешать спор напрямую, ввиду 34 и 35 апостольского правила, которые закрепляют права одного (действующего) епископа на одной территории, которому воздается честь и без которого не решаются вопросы в его юрисдикции. «Апелляция к былой славе Константинополя не имеет ничего общего с современным состоянием Вселенского Патриархата. Все религиозные привилегии были производны от политического статуса города, с потерей политического значения Константинополя были утрачены и религиозные права Константинополя и Константинопольского Патриархата. Тем не менее, Константинопольский Патриархат использует каноническую базу и историческое прошлое для достижения своей цели» [8, с. 43]. Канонические правила и постановления императоров не приписывают Вселенскому патриарху права управления там, где есть действующий епископ, не в его юрисдикции. С этой точки зрения вмешательства Вселенского патриархата в дела УПЦ в Украине противоречат как канонам, так и истории Вселенской Церкви.

Грамота, переданная патриархом Алексием II киевскому митрополиту в 1990 г., в которой говорится о предоставлении независимости и самостоятельности в управлении УПЦ вполне отражает обычай, вошедший возведенный в правовую норму и не нарушенный со стороны РПЦ.

\section{Литература:}

1. Барон Ю. Система римского гражданского права. Санкт-Петербург, 1909. 305 с. 
2. Гримм Д. Д. Лекции по догме римского права. Москва, 2003. $304 \mathrm{c}$.

3. Киприан Карфагенский. Письмо к Помпею против письма Стефана о крещении еретиков: Сборник писем. Москва, 2008. 340 с.

4. Климент Александрийский. Строматы. Санкт-Петербург, 2003. $302 \mathrm{c}$.

5. Никодим Милаш. Православное церковное право. Санкт-Петербург, 1897. 400 с.

6. Никодим Святогорец. Пидалион: в 4 т. Т. 3. Екатеринбург, 2019. $260 \mathrm{c}$.

7. Никодим Святогорец. Пидалион: в 4 т. Т. 2. Екатеринбург. 2019. $270 \mathrm{c}$.

8. Ухтомский А. А. Православная диаспора: проблема формирования канонического статуса. Церковь и время. 2009. № 3 (48). Москва, 158 с.

9. Цыпин В., Каноническое право. Москва, 2009. 720 с.

10. Энгельман И. Е. О давности по русскому гражданскому праву: историко-догматическое исследование. URL: http://civil.consultant.ru/ elib/books/2/page_15.html\#ftn_70 (дата обращения: 25.02.2021)

DOI https://doi.org/10.30525/978-9934-26-040-7-15

\title{
СУЧАСНИЙ ТЕОРЕТИКО-ПРАВОВИЙ ПІДХІД ДО РОЗУМІННЯ ЗАХИСТУ ПРАВ ЛЮДИНИ
}

\author{
Чепульченко Т. 0. \\ кандидат юридичних наук,
} дочент кафедри публічного права факультету соиіології і права Національного технічного університету України «Київський політехнічний інститут імені Ігоря Сікорського» м. Київ, Украӥна

Проблема захисту прав людини займає гідне місце у науковій правовій доктрині. Втім, незважаючи на значні здобутки вчених у даній сфері, а також на існування системи актів національного законодавства 3 питань захисту прав людини, комплексу актів міжнародного права, згоду на обов’язковість яких надано Верховною Радою України, 